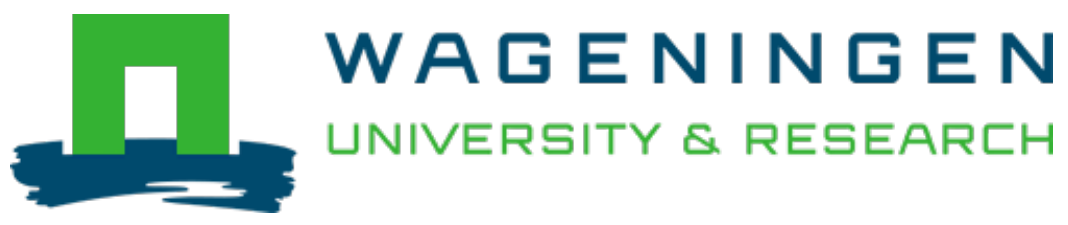

\title{
Location and limitation of cellulose production by Acetobacter xylinum established from oxygen profiles
}

\author{
Journal of Bioscience and Bioengineering \\ Verschuren, P.G.; Cardona, T.D.; Nout, M.J.R.; Gooijer, K.D.; Heuvel, J.C. \\ https://doi.org/10.1016/S1389-1723(00)89089-1
}

This publication is made publicly available in the institutional repository of Wageningen University and Research, under the terms of article $25 \mathrm{fa}$ of the Dutch Copyright Act, also known as the Amendment Taverne. This has been done with explicit consent by the author.

Article 25 fa states that the author of a short scientific work funded either wholly or partially by Dutch public funds is entitled to make that work publicly available for no consideration following a reasonable period of time after the work was first published, provided that clear reference is made to the source of the first publication of the work.

This publication is distributed under The Association of Universities in the Netherlands (VSNU) 'Article $25 \mathrm{fa}$ implementation' project. In this project research outputs of researchers employed by Dutch Universities that comply with the legal requirements of Article $25 \mathrm{fa}$ of the Dutch Copyright Act are distributed online and free of cost or other barriers in institutional repositories. Research outputs are distributed six months after their first online publication in the original published version and with proper attribution to the source of the original publication.

You are permitted to download and use the publication for personal purposes. All rights remain with the author(s) and / or copyright owner(s) of this work. Any use of the publication or parts of it other than authorised under article $25 \mathrm{fa}$ of the Dutch Copyright act is prohibited. Wageningen University \& Research and the author(s) of this publication shall not be held responsible or liable for any damages resulting from your (re)use of this publication.

For questions regarding the public availability of this publication please contact openscience.library@wur.nl 


\title{
Location and Limitation of Cellulose Production by Acetobacter xylinum Established from Oxygen Profiles
}

\author{
PETER G. VERSCHUREN, ${ }^{1 *}$ THOMAS D. CARDONA, ${ }^{2}$ M. J. ROBERT NOUT,${ }^{3}$ KEES D. DE GOOIJER, ${ }^{3}$ \\ AND JOHANNES C. VAN DEN HEUVEL ${ }^{1}$ \\ Department of Chemical Engineering, University of Amsterdam, Nieuwe Achtergracht 166, 1018 WV Amsterdam, The \\ Netherlands, ${ }^{1}$ Department of Food Science \& Technology, University of New South Wales, Sydney 2052, \\ Australia, ${ }^{2}$ and Department of Food Technology and Nutritional Sciences, Wageningen \\ Agricultural University, Bomenweg 2, 6703 HD Wageningen, The Netherlands ${ }^{3}$
}

Received 5 July 1999/Accepted 30 December 1999

\begin{abstract}
The static fermentation of coconut water sucrose by Acetobacter xylinum was carried out at initial pH's of 3.0, 4.0, 5.0 or 6.0. Cellulose was produced at the surface, and its production was most favourable at pH's 4.0 and 5.0. These pH values also allowed for optimal bacterial growth. Oxygen concentration profiles were measured with microelectrodes at different cultivation stages, and steep profiles were obtained with penetration depths between 50 and $100 \mathrm{\mu m}$. A substrate penetration depth analysis confirmed the hypothesis that the first stage of the fermentation is entirely oxygen controlled. Diffusion calculations showed, however, that at a later stage sucrose becomes a limiting substrate also, which was confirmed by the decrease in cellulose production rate over time. The effective diffusion coefficient of oxygen in deactivated cellulose pellicles was measured with microelectrodes, and a value of $1.4 \times 10^{-9} \mathrm{~m}^{2} / \mathrm{s}$ was obtained under all investigated conditions. The oxygen flux was $5.9 \times 10^{-6} \mathrm{~mol} / \mathrm{m}^{2} \cdot \mathrm{s}$, while a significantly higher value of $9.1 \times 10^{-6} \mathrm{~mol} / \mathrm{m}^{2} \cdot \mathrm{s}$ was obtained at $\mathrm{pH} 4.0$.
\end{abstract}

[Key words: oxygen profile, diffusion, microelectrode, Acetobacter xylinum, nata de coco]

Microbial cellulose, in the Philippines known as nata de coco, is used in sweetened form as dessert, as an ingredient in food products and cosmetics, and as an additive in the manufacture of cloth, high grade papers, and membrane materials $(1,2)$. It is produced at the surface of coconut water and other suitable media by a gram-negative rodshaped bacterium, Acetobacter xylinum (3). The fermentation is carried out in static cultures at $30^{\circ} \mathrm{C}$ in acidic $\mathrm{pH}$ from 3.5 to 7.0. As the organism is obligate aerobic, it is thought that cellulose is produced at the air/liquid interface, where the cells can obtain oxygen (4). In static cultures, substrates have to be transported entirely by diffusion, and as carbon sources are generally available, the oxygen supply is considered as the limiting factor for growth and cellulose production. Moreover, diffusion rates will be reduced gradually due to the formation of cellulose at the surface. To date, there is no information available concerning the oxygen concentration in the medium or the changes in the local oxygen concentration during fermentation. However, it is quite likely that substantial concentration profiles will develop.

In this study, we investigated the influence of the initial $\mathrm{pH}$ in the relevant range of 3.0-6.0 on the rate of cellulose production, the development of oxygen concentration gradients, and the effective diffusion coefficient $D_{\mathrm{e}}$ of oxygen in the produced pellicle. Microelectrodes with tip diameters in the $\mu \mathrm{m}$ range have been employed successfully in the field of biotechnology to measure the amount of dissolved oxygen for the past two decades (58). A high spatial resolution can be achieved, enabling the measurement of local concentration gradients inside biofilms without disturbing them. To determine the oxygen diffusion coefficients, we applied the transient state method as described by Cronenberg and Van den Heuvel (9). Microelectrodes were positioned at a fixed place in-

\footnotetext{
* Corresponding author.
}

side the deactivated biofilm pellicle, followed by a stepwise concentration change in the bulk of the liquid, and the subsequent response was monitored as a function of time.

\section{MATERIALS AND METHODS}

General All reagents and chemicals used were of analytical grade, unless stated otherwise.

Organism The Acetobacter xylinum strain was isolated from nata de coco and was supplied by Kasetsart University, Bangkok, Thailand.

Experimental fermentations

For the purpose of oxygen concentration measurements, fermentations were carried out in test tubes $(\phi 15 \mathrm{~mm})$ containing $9.5 \mathrm{ml}$ of sterilized and $\mathrm{pH}$-adjusted coconut water sucrose (CWS) medium. Each tube was inoculated with $0.5 \mathrm{ml}$ of a preculture grown at $30^{\circ} \mathrm{C}$ for $72-96 \mathrm{~h}$ in a rotary shaker, giving an initial cell density of log CFU (colony forming units) $/ \mathrm{g}=7.5$. For each $\mathrm{pH}$ value, 12 replicate fermentation tubes were inoculated and incubated at $30^{\circ} \mathrm{C}$ under static conditions.

Media The CWS medium consisted of $20.0 \mathrm{~g} \mathrm{su-}$ crose, $5.0 \mathrm{~g}\left(\mathrm{NH}_{4}\right)_{3} \mathrm{PO}_{4}$, and $5.0 \mathrm{~g}$ glacial acetic acid dissolved in $1.0 \mathrm{l}$ of coconut water. Coconut water was obtained from coconuts purchased locally (Wageningen). The initial pH was adjusted to $3.00,4.00,5.00$ or 6.00 with $0.1 \mathrm{M} \mathrm{H}_{3} \mathrm{PO}_{4}$ or sterilized $0.5 \mathrm{M} \mathrm{NaOH}$. The composition of the peptone saline solution (10) was $1.0 \mathrm{~g}$ of bacto-peptone, and $8.5 \mathrm{~g}$ of sodium chloride in $1.0 \mathrm{l}$ of distilled water.

The composition of the modified Schramm, Gromet and Hestrin (SGH) plating medium (11) was $20.0 \mathrm{~g}$ of glucose, $5.0 \mathrm{~g}$ of yeast extract, $5.0 \mathrm{~g}$ of bacto-peptone, $1.0 \mathrm{~g}$ of $\mathrm{K}_{2} \mathrm{HPO}_{4}, 10.0 \mathrm{~g}$ of agar, and $5.0 \mathrm{~g}$ of glacial acetic acid in $1.0 \mathrm{l}$ of distilled water. All media were autoclaved for $20 \mathrm{~min}$ at $121^{\circ} \mathrm{C}$. Glacial acetic acid was 
added aseptically after the media had cooled below $50^{\circ} \mathrm{C}$. Oxygen microelectrodes and profiles Combined oxygen microsensors with a tip diameter of $10 \mu \mathrm{m}$ were prepared according to the method of Revsbech and Ward (12). The electrode was mounted vertically on a motordriven micromanipulator and placed inside a Faraday cage to reduce electromagnetic interference. The electrical current was measured with an amperometer (Keithley 617, Cleveland, USA). The test tubes were removed from the incubator and immersed in a $30^{\circ} \mathrm{C}$ water bath. Due to the roughness of the surface of the pellicle on a microscopic scale, a precise visual determination of the interface was impossible. Hence, the electrode was lowered at steps of $1 \mu \mathrm{m}$ until a decrease in the signal was observed, and this point was considered to be the film/air interface.

From days 1 to 7 after inoculation, two different tubes from every set of initial $\mathrm{pH}$ values were randomly selected for the oxygen profile measurements. From day 9 onwards, the same set of two tubes was used, and profiles were measured in the center of the pellicle and at a distance of $4 \mathrm{~mm}$ from the edge of the tube.

Oxygen diffusion coefficient To determine the effective diffusion coefficient $\left(D_{\mathrm{e}}\right)$, a transient state measurement was carried out in pellicles grown at different initial $\mathrm{pH}$ values. At the end of the fermentation the microbial activity was inhibited by adding a solution of sodium azide (final concentration $0.2 \%$ ). The tubes were exposed to air for 1 week, allowing the contents to be fully saturated with air. Due to the 'elasticity' of the pellicle material, which induces a compressed diffusion barrier in front of the electrode tip, the output of the electrode was severely reduced when the penetration depth exceeded $300 \mu \mathrm{m}$. Similar problems have been described in the literature regarding several immobilization materials, and for details the reader is referred to Müller et al. (13). Therefore, a special procedure was required, viz., the tip of the microelectrode was driven first to a depth of approximately $1500 \mu \mathrm{m}$, and subsequently withdrawn to the desired depth of $1000 \mu \mathrm{m}$. In general, this was sufficient to regain the calibration signal; however, in some cases this procedure had to be repeated several times. Unfortunately, a stepwise increase in the concentration by means of gaseous oxygen decreased the pellicle thickness during the measurement due to the evaporation of water. Therefore, after a stabilization period of $30 \mathrm{~min}$ for the electrode a stepwise increase in oxygen concentration from 0.24 to $1.14 \mathrm{~mol} / \mathrm{m}^{3}$ was applied by adding $2 \mathrm{ml}$ of water saturated with pure oxygen on the top of the pellicle. During the measurement, pure oxygen was continuously bubbled through this liquid layer to keep it oxygen-saturated, and to minimize the stagnant liquid boundary layer. The resulting changes in the output of the microelectrode were monitored continuously for about $3 \mathrm{~h}$ by means of a recorder. The effective diffusion coefficient $\left(D_{\mathrm{e}}\right)$ was obtained by fitting the time-dependent oxygen concentration $C$ to the theoretical response for a flat slab (14):

$$
\begin{aligned}
& \frac{C-C_{0}}{C_{\mathrm{s}}-C_{0}}=1-\frac{4}{\pi} \cdot \sum_{\mathrm{n}=0}^{\infty} \frac{(-1)^{\mathrm{n}}}{2 n+1} \cdot \cos \\
& \quad\left[(2 n+1) \frac{\pi r}{2 L}\right] \cdot \exp \left\{-\left[(2 n+1) \frac{\pi}{2 L}\right]^{2} D_{\mathrm{e}} \cdot t\right\}
\end{aligned}
$$

where $C_{\mathrm{s}}$ is the oxygen concentration in the bulk liquid $\left(\mathrm{mol} / \mathrm{m}^{3}\right), C_{0}$ the initial oxygen concentration, $L$ the total depth of the slab $\left(5 \times 10^{-2} \mathrm{~m}\right), r$ the position of the electrode from the bottom of the slab $\left(4.9 \times 10^{-2} \mathrm{~m}\right), D_{\mathrm{e}}$ the effective diffusion coefficient $\left(\mathrm{m}^{2} / \mathrm{s}\right)$, and $t$ the time (s). The signal was corrected for the drift of the electrode (less than $2 \% / \mathrm{h}$ ), and all measurements were carried out in duplicate. To simplify the calculations it was assumed that the mass transfer resistance due to the stagnant liquid boundary layer at the top of the pellicle was negligible, and that the medium exhibited the same diffusion coefficient as the cellulose pellicle.

Oxygen fluxes The oxygen flux $J$ through the interface was calculated according to Fick's first law of diffusion:

$$
J=-D_{\mathrm{e}}(\mathrm{d} C / \mathrm{d} x)
$$

where $J$ is the flux of oxygen $\left(\mathrm{mol} / \mathrm{m}^{2} \cdot \mathrm{s}\right)$, and $\mathrm{d} C / \mathrm{d} x$ the local oxygen concentration gradient. $C$ equals $0.24 \mathrm{~mol} /$ $\mathrm{m}^{3}$ at $30^{\circ} \mathrm{C}$.

Moisture content The cellulose pellicle was lifted with tweezers, weighed and subsequently dried in an oven for $16 \mathrm{~h}$ at $80^{\circ} \mathrm{C}$. The moisture content $(\% \mathrm{w} / \mathrm{w})$ was calculated based on the weight loss of the pellicle.

Total viable counts The pellicle was cut into small pieces with sterile scalpels, and placed in a sterile plastic bag. Then, a peptone saline solution 9-fold the weight of the cut pellicles was added, and the contents were pressed manually for $2 \mathrm{~min}$ to obtain a tenfold diluted suspension. The number of viable cells (TVC) expressed as $\log \mathrm{CFU} / \mathrm{g}$ was determined using serial decimal dilutions on agar plates with the $\mathrm{SGH}$ medium. Colonies were counted after $4 \mathrm{~d}$ of incubation at $30^{\circ} \mathrm{C}$.

\section{RESULTS}

Pellicle development The effect of the initial $\mathrm{pH}$ in the range 3.0 to 6.0 on the cellulose production rate of Acetobacter xylinum was determined. Figure 1 shows that cellulose formation is the most favourable at an initial $\mathrm{pH}$ of 5.0, with $\mathrm{pH} 4.0$ as the next best. The deviation in the final pellicle thickness was $\pm 5 \%$. At pH 6.0 the initial formation was retarded, but from day 3 onwards the same cellulose synthesis rate was observed. Cellulose formation rates gradually decreased over the course of time, and beyond day 11 the rate was reduced to about $25 \%$. The changes in total viable counts

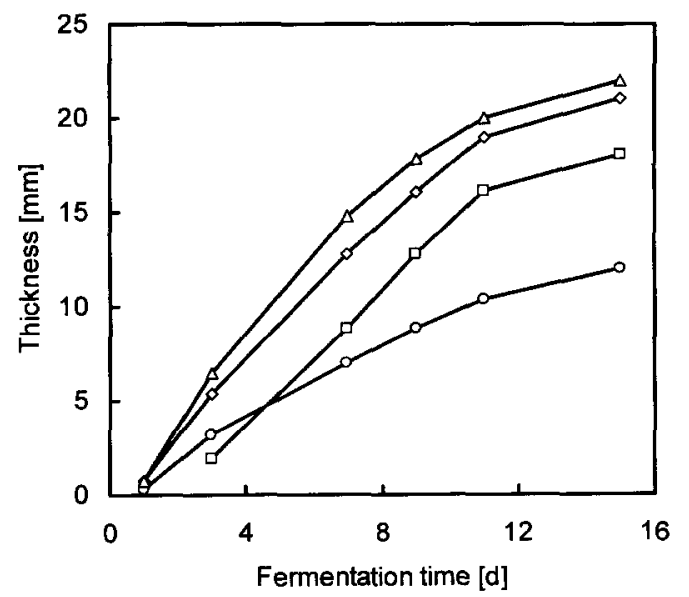

FIG. 1. Pellicle thickness during the course of fermentation at initial pH values of $3.0(O), 4.0(\diamond), 5.0(\Delta)$, and $6.0(\square)$. 
(TVC), $\mathrm{pH}$ and moisture content are summarized in Table 1. The concentration of viable cells decreased at all investigated $\mathrm{pH}$ values. Among the tested $\mathrm{pH}$ values, the highest cell counts on days 3 and 7 were obtained at pH 4.0. On the other hand, the highest cell counts on day 9 and beyond were obtained at pH's 4.0 and 5.0. The $\mathrm{pH}$ value of the medium remained within 0.2 units of the initial $\mathrm{pH}$, except for $\mathrm{pH} 6.0$, which gradually decreased to 5.37. The moisture content was the same for all pellicles, irrespective of the initial $\mathrm{pH}$ value and the cultivation time.

Oxygen profiles Figures $2 \mathrm{a}-\mathrm{d}$ show the development of the oxygen concentration gradients in the course of the fermentation at initial $\mathrm{pH}$ values of 3.0, 4.0, 5.0, and 6.0 , respectively. After one day, the steepest profiles were observed at pH 4.0, reducing the oxygen penetration depth to less than $200 \mu \mathrm{m}$. For the same period, a penetration depth of $400-500 \mu \mathrm{m}$ was observed at pH's 3.0 and 5.0, while at $\mathrm{pH} 6.0$, air saturation still amounted to $30 \%$ at a depth of $2 \mathrm{~mm}$ (data not shown). On day 3 , the reaction zone was limited to $100 \mu \mathrm{m}$ or less, except at $\mathrm{pH} 6.0$. On day 7 , all of the oxygen profiles were less than $100 \mu \mathrm{m}$, while those at $\mathrm{pH} 4.0$ were reduced even further to $50 \mu \mathrm{m}$. These are typical values often ob- served for biological systems $(5,6,8,15)$. Beyond day 7 no significant changes in the slopes of the oxygen profiles were observed.

Diffusion coefficients After deactivation of the microorganisms with sodium azide, oxygen gradients were no longer observed. Reproducible responses were obtained, and a characteristic response to a stepwise increase in the oxygen concentration is shown in Fig. 3. For this specific pellicle (pH 4.0), a good fit was obtained with a $D_{\mathrm{e}}$ value of $1.4 \times 10^{-9} \mathrm{~m}^{2} / \mathrm{s}$. No significant differences were found between diffusion coefficients in cellulose produced at different initial $\mathrm{pH}$ values. The average $D_{\mathrm{e}}$ for oxygen was $1.4( \pm 0.2) \times 10^{-9} \mathrm{~m}^{2} / \mathrm{s}$.

Oxygen fluxes Oxygen fluxes were calculated from the linear part of the slopes of the profiles (Fig. 2) and the diffusion coefficient $D_{\mathrm{e}}$, according to Fick's first law of diffusion. The average fluxes were calculated from 2-4 measurements and are presented in Table 1. Oxygen fiuxes did not change after day 3, except at pH 6.0 where a constant flux was reached from day 7 onwards. The average oxygen flux between day 3 and 15 was 9.1 $( \pm 0.8) \times 10^{-6} \mathrm{~mol} / \mathrm{m}^{2} \cdot \mathrm{s}$ at $\mathrm{pH} 4.0$, while at the other $\mathrm{pH}$ values, a much lower average value of $5.9( \pm 1.1) \times 10^{-6}$ $\mathrm{mol} / \mathrm{m}^{2} \cdot \mathrm{s}$ was obtained.
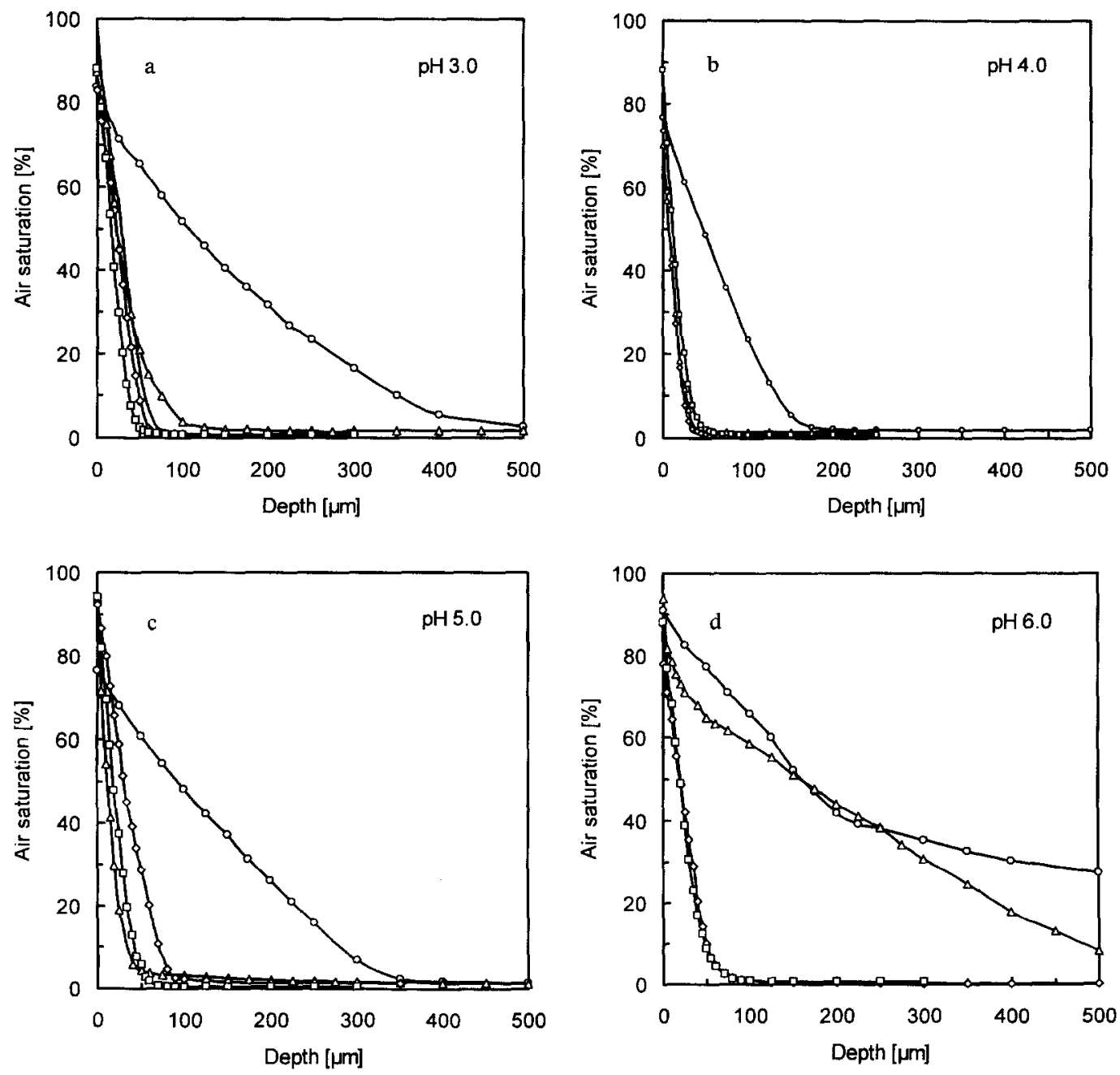

FIG. 2. (a-d) Typical oxygen profiles at an initial pH of 3.0, 4.0, 5.0, and 6.0 at day $1(\bigcirc), 3(\triangle), 7(\diamond)$, and $15(\square)$ of fermentation. 
TABLE 1. Changes in oxygen flux, total viable count (TVC), moisture content, and $\mathrm{pH}$ during the course of fermentation at different initial $\mathrm{pH}$ values

\begin{tabular}{llcccccc}
\hline \multirow{2}{*}{$\begin{array}{c}\text { Initial } \\
(\mathrm{pH})\end{array}$} & \multirow{2}{*}{ Parameter } & \multicolumn{6}{c}{ Fermentation (d) } \\
\cline { 3 - 8 } & & $1^{\mathrm{a}}$ & 3 & 7 & 9 & 11 & 15 \\
\hline 3.00 & Flux $\left(10^{-6} \mathrm{~mol} / \mathrm{m}^{2} \cdot \mathrm{s}\right)$ & 1.8 & 5.8 & 5.5 & 4.2 & 8.5 & 6.8 \\
& TVC $(\log \mathrm{CFU} / \mathrm{g})$ & nd & 6.8 & 6.1 & nd & nd & 2.5 \\
& Moisture $(\% \mathrm{w} / \mathrm{w})$ & nd & 88.6 & 90.8 & 90.9 & 90.7 & 90.8 \\
& pH & nd & 3.09 & 3.01 & 3.04 & 3.00 & 2.96 \\
\hline \multirow{2}{*}{4.00} & Flux $\left(10^{-6} \mathrm{~mol} / \mathrm{m}^{2} \cdot \mathrm{s}\right)$ & 4.0 & 7.8 & 9.3 & 9.1 & 9.2 & 9.9 \\
& TVC $(\log \mathrm{CFU} / \mathrm{g})$ & nd & 8.1 & 7.3 & 6.0 & 5.9 & 5.7 \\
& Moisture $(\% \mathrm{w} / \mathrm{w})$ & nd & 90.2 & 88.9 & 91.1 & 91.2 & 91.1 \\
& $\mathrm{pH}$ & nd & 3.92 & 3.88 & 3.93 & 3.83 & 3.82 \\
\hline 5.00 & Flux $\left(10^{-6} \mathrm{~mol} / \mathrm{m}^{2} \cdot \mathrm{s}\right)$ & 1.3 & 7.2 & 4.7 & 6.0 & 5.2 & 6.4 \\
& TVC $(\log \mathrm{CFU} / \mathrm{g})$ & nd & 6.5 & 6.3 & 6.3 & 5.2 & 5.7 \\
& Moisture $(\% \mathrm{w} / \mathrm{w})$ & nd & 90.2 & 90.4 & 90.3 & 90.4 & 90.4 \\
& $\mathrm{pH}$ & nd & 4.80 & 4.80 & 4.91 & 4.83 & 4.85 \\
\hline 6.00 & Flux $\left(10^{-6} \mathrm{~mol} / \mathrm{m}^{2} \cdot \mathrm{s}\right)$ & 1.3 & 0.67 & 5.1 & 5.4 & 6.2 & 5.2 \\
& TVC (log CFU/g) & nd & nd & nd & 5.3 & 4.5 & 4.5 \\
& Moisture $(\% \mathrm{w} / \mathrm{w})$ & nd & nd & nd & 90.1 & 90.5 & 90.2 \\
& $\mathrm{pH}$ & nd & 5.64 & 5.52 & 5.54 & 5.44 & 5.37 \\
\hline
\end{tabular}

a Flux calculated with $\mathrm{D}$ of oxygen in water.

nd, Not determined.

\section{DISCUSSION}

The highest cellulose formation rate at initial $\mathrm{pH}$ values of 4.0 and 5.0 is in good agreement with results of earlier studies (16-18). These $\mathrm{pH}$ values also allowed for optimal bacterial growth, and coincide well with pH 4.5 as the optimum reported by Embuscado et al. (17), particularly with regard to strain variety (2). The overall cellular densities were low, but in the same order as those obtained by Embuscado et al. (17), viz., 5-7 log $\mathrm{CFU} / \mathrm{g}$. However, if we assume that most of the viable cells are concentrated in the oxygen-penetrated zone for $\mathrm{pH} 4.0$ on day $7, \log \mathrm{CFU} / \mathrm{g}$ would be $7.3+\log$ $260=9.8$, since the thickness of the pellicle was $13 \mathrm{~mm}$ (Fig. 1), and the upper active layer was $50 \mu \mathrm{m}$ (Fig. 2b). According to Hestrin and Schramm (19), the concentration of freeze-dried A. xylinum cells is approximately $10^{12}$ cells/g, corresponding to $11 \log \mathrm{CFU} / \mathrm{g}$ for hydrated cells, assuming 10\% dry weight. Thus, if our hypothesis is correct, the upper layer consists of about $10 \%$ of cells. Hestrin and Schramm (19) also determined the oxygen uptake rate of pure cells $\left(10^{17} \mathrm{cells} / \mathrm{m}^{3}\right)$ of $A . x y l i$ num to be $1.2 \mathrm{~mol} / \mathrm{m}^{3} \cdot \mathrm{s}$. The oxygen consumption rate $R\left(\mathrm{~mol} / \mathrm{m}^{3} \cdot \mathrm{s}\right)$ can be calculated from the oxygen flux $J=R \cdot \delta$, in which $\delta(\mathrm{m})$ is the depth of the reaction zone. For day 7 at pH 4.0 (Table 1), with $J=9.3 \times 10^{-6} \mathrm{~mol} /$ $\mathrm{m}^{2} \cdot \mathrm{s}$ and $\delta=50 \mu \mathrm{m}$, a value of $0.19 \mathrm{~mol} / \mathrm{m}^{3} \cdot \mathrm{s}$ is obtained, which is about $15 \%$ of the activity of pure cells. Although a rough estimation, this value corresponds well with the previously estimated concentration of $10 \%$ of cells.

On days 3 and 7 of the fermentation at $\mathrm{pH} 4.0$, the steepest oxygen profiles corresponded well with the highest cell concentrations (TVC). Interestingly, from day 9 onwards, the oxygen flux at $\mathrm{pH} 4.0$ was $50 \%$

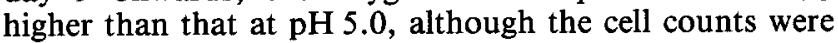
virtually the same for cultures at $\mathrm{pH}$ 's 4.0 and 5.0. Notwithstanding the higher oxygen flux at $\mathrm{pH} 4.0$, the same amount of cellulose was produced per unit of time at pH 5.0. Furthermore, at pH 3.0 oxygen fluxes equalled those of $\mathrm{pH} 5.0$, while the cellulose production rate was

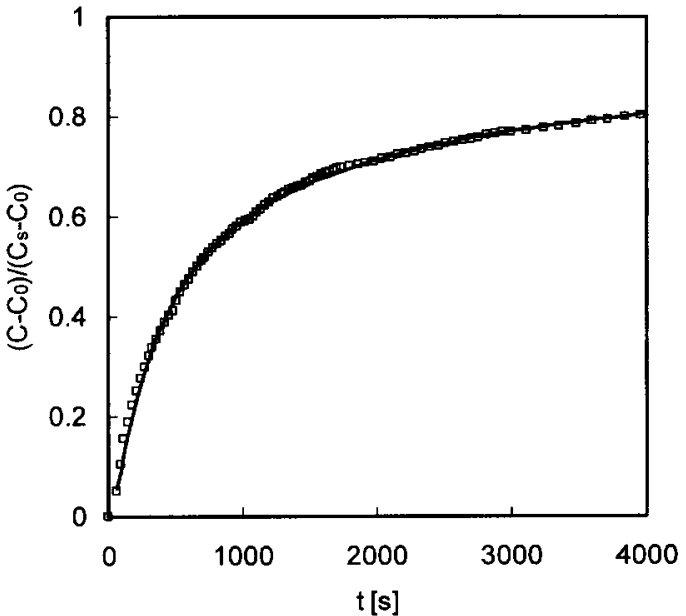

FIG. 3. Typical response to a stepwise increase in oxygen concentration in a cellulose pellicle (initial $\mathrm{pH} 4.0$ ) measured with a microelectrode. The solid line indicates the theoretical response at a depth of $1000 \mu \mathrm{m}$ and with a diffusion coefficient $D_{\mathrm{e}}$ of $1.4 \times 10^{-9}$ $\mathrm{m}^{2} / \mathrm{s}$.

only $50 \%$. Similar results were obtained by Hestrin and Schramm (19): at $\mathrm{pH} 3.0$ their cellulose synthesis rate was only $20 \%$ compared to that at $\mathrm{pH} 5.0$, while the corresponding oxygen uptake rate was $75 \%$. The continuous decrease in the number of viable cells in the course of fermentation, and the decrease in cellulose formation rate beyond day 11 did not affect the oxygen concentration profiles, i.e., oxygen uptake rates. These results indicate that there is no direct relationship between cellulose formation and oxygen demand, and consequently other oxygen-consuming processes have to play a role. $A$. $x y l i$ num is known to oxidize glucose at high concentrations to gluconic acid with a concomitant $\mathrm{pH}$ decrease $(16,17$, $20,21)$. Unfortunately, the high-buffer capacity of the medium in the lower $\mathrm{pH}$ range would have prohibited this decrease, and except at $\mathrm{pH} 6.0$, no significant $\mathrm{pH}$ decrease was observed. Another explanation might be that at less favourable lower $\mathrm{pH}$ values, more oxygen is used for cell maintenance.

Borzani and de Souza (22) found by means of tracer experiments that the formation of cellulose occurs at the film/air interface. Masaoka et al. (16) came to the same conclusion, yet no fundamental mechanism was proposed by these authors. Our experiments, however, determined a $50-100 \mu \mathrm{m}$ active upper zone in which cellulose is formed exclusively. It should be emphasized that such steep oxygen profiles are typical of various biological systems $(5,6,8,15)$. Due to oxygen limitation, which occurs in the early stage of fermentation, cell growth and cellulose production only occur in this narrow zone at the air/medium interface. The cellulose pellicle floats on the liquid, and the produced cellulose is pushed down in the course of time, while new cellulose layers are constantly built on top of the mature cellulose. Three factors are involved in this phenomenon: (i) the transport distance of sucrose to the reaction zone at the top is much greater than that for oxygen; (ii) the diffusion coefficient of sucrose is almost five times smaller than that of oxygen in water, i.e., $6.2 \times 10^{-10}$ and $2.8 \times 10^{-9}$ $\mathrm{m}^{2} / \mathrm{s}(23,24)$, respectively; and (iii) the maximum oxygen concentration in the reaction zone is much less than the sucrose concentration in the broth $\left(0.24 \mathrm{vs}\right.$. $\left.>58 \mathrm{~mol} / \mathrm{m}^{3}\right)$. 


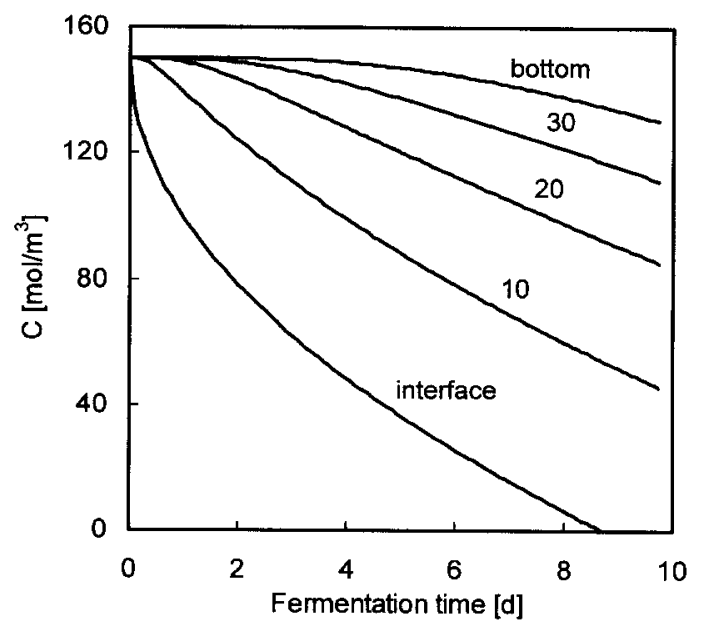

FIG. 4. Calculated sucrose concentration with respect to time at different depths, i.e., the reaction zone/medium interface, at depths of 10,20 , and $30 \mathrm{~mm}$, and the bottom.

If the hypothesis that cellulose is only formed in the reaction zone is correct, then the penetration depth of sucrose from below should be significantly larger than that of oxygen from above.

Assuming a zero-order kinetics, the penetration depth ( $\delta$ ) can be estimated by $(25)$ :

$$
\delta=\sqrt{\frac{2 D_{\mathrm{e}} C_{\mathrm{i}}}{R}}
$$

where $C_{\mathrm{i}}$ is the sucrose concentration at the interface $\left(\mathrm{mol} / \mathrm{m}^{3}\right)$. The sucrose consumption rate $R$ can be estimated from a simplified metabolic reaction:

$$
\begin{aligned}
& \text { Sucrose }+12 \mathrm{O}_{2} \rightarrow 12 \mathrm{CO}_{2}+12 \mathrm{H}_{2} \mathrm{O} \\
& \text { Sucrose } \rightarrow \text { Cellulose }
\end{aligned}
$$

Hence, sucrose is consumed for two purposes. From Fig. 1 it can be seen that $2 \mathrm{~mm}$ of pellicle is formed per day between days 3 and 7 at pH 4.0. With a tube diameter of $15 \mathrm{~mm}$, an assumed density of $10^{3} \mathrm{~kg} / \mathrm{m}^{3}$, and a dry matter content of $10 \%$ (Table 1) this translates into a maximum cellulose production rate of $4.0 \times 10^{-10}$ $\mathrm{kg} \mathrm{dw} / \mathrm{s}$ on day 7 . With a molecular weight of 342 for sucrose, and a reaction zone $50 \mu \mathrm{m}$ thick where both oxygen and sucrose are consumed (Fig. 2b), the estimated sucrose uptake rate for pellicle formation is $0.13 \mathrm{~mol} /$ $\mathrm{m}^{3} \cdot \mathrm{s}$. The consumption rate for oxygen at day 7 was calculated earlier to be $0.19 \mathrm{~mol} / \mathrm{m}^{3} \cdot \mathrm{s}$. The concomitant sucrose consumption rate for growth and maintenance can be derived from Eq. 4 and is determined to be $0.016 \mathrm{~mol} / \mathrm{m}^{3} \cdot \mathrm{s}$. Thus, the total sucrose consumption rate adds up to $0.15 \mathrm{~mol} / \mathrm{m}^{3} \cdot \mathrm{s}$. Assuming that $C_{\mathrm{i}}$ is equal to the initial bulk concentration, a condition valid only in the early stage of fermentation, Eq. 3 yields a maximal penetration depth of $500 \mu \mathrm{m}$. Thus, the penetration depth for sucrose is 10 times larger than that for oxygen, indicating that for the early stage of fermentation, oxygen is indeed the limiting substrate.

In a later stage, sucrose will become a limiting substrate also, due to the large transport distance. The static medium can be considered to be a plane sheet with a uniform initial concentration $C_{0}$, one impermeable bottom surface and a constant sucrose flux from the reaction zone/medium interface (14). Figure 4 shows the calculated sucrose concentration with respect to time at different depths, i.e., the reaction zone/medium interface, at depths of 10,20 , and $30 \mathrm{~mm}$, and the bottom. The initial sucrose concentration was assumed to be $150 \mathrm{~mol} / \mathrm{m}^{3}$, since coconut water contains approximately $30 \mathrm{~g} / l$ saccharides (26), while the reaction rate was assumed to be $50 \%$ of the previously estimated value because part of the dry weight is composed of salts and non reacted sugars. Since only a small part of the sheet consists of cellulose, the diffusion coefficient for water was used for simplicity. According to these calculations, the sucrose concentration at the interface will approach zero, long before its concentration in the medium is exhausted. In actual conditions, however, the reaction rate and thus the flux will decrease when the sucrose concentration at the interface nears the saturation constant $K_{\mathrm{s}}$. These calculations are confirmed by the gradual decrease in the cellulose production rate over time. From Fig. 4 it is also clear that the macroscopic determination of the sucrose concentration in the bulk liquid at best will only yield an average concentration, and will not yield any information at all concerning the relevant concentration at the interface.

The measured diffusion coefficient for oxygen in the cellulose pellicle is in good accordance with those in several gel support materials, e.g., $D_{\mathrm{e}}$ values of $1.5 \times 10^{-9}$ to $2.1 \times 10^{-9} \mathrm{~m}^{2} / \mathrm{s}$ were obtained for $0.5-5 \% \mathrm{w} / \mathrm{v} \kappa$-carrageenan, alginate and gellan gum, respectively $(27,28)$. As the moisture content and diffusion coefficients were very similar for pellicles grown at different $\mathrm{pH}$ values, it seems reasonable to conclude that the $\mathrm{pH}$ has no influence on the physical properties of cellulose produced by $A$. xylinum.

Conclusion The mechanism underlying cellulose formation was established; the oxygen profiles unequivocally demonstrate that the fermentation of coconut water sucrose by $A$. xylinum occurs at the film/air interface zone of $50-100 \mu \mathrm{m}$. A penetration depth analysis showed that during the early part of fermentation, oxygen was indeed the limiting substrate. However, calculations showed that in a later stage, sucrose also becomes a limiting substrate, and this might explain the gradual decrease in the cellulose production rate.

The effective diffusion coefficient $\left(D_{\mathrm{e}}\right)$ for oxygen was $1.4 \times 10^{-9} \mathrm{~m}^{2} / \mathrm{s}$, which is about $50 \%$ of that for water. The diffusion coefficient and moisture content of the cellulose pellicles were not influenced by the $\mathrm{pH}$. The $\mathrm{pH}$ for optimal cellulose production and bacterial growth is between 4.0 and 5.0, while the highest oxygen uptake rate occurs at $\mathrm{pH} 4.0$.

\section{REFERENCES}

1. White, D. G. and Brown, R. M.: Prospects for the commercialization of the biosynthesis of microbial cellulose, p. 573-590. In Schuerch, C. (ed.), Cellulose and wood-chemistry and technology. John Wiley \& Sons, New York (1989).

2. Cannon, R. E. and Anderson, S. M.: Biogenesis of bacterial cellulose. Crit. Rev. Microbiol., 17, 435-447 (1991).

3. Krieg, N. R. and Holt, J. C. (ed.): Bergey's manual of systematic bacteriology, vol. 1, p. 267-274. Williams \& Wilkins, Baltimore (1984).

4. Schramm, M. and Hestrin, S.: Factors affecting production of cellulose at the air/liquid interface of a culture of Acetobacter xylinum. J. Gen. Microbiol., 11, 123-129 (1954).

5. De Beer, D. and Van den Heuvel, J. C.: Gradients in immobilized biological systems. Anal. Chim. Acta, 213, 259-265 (1988). 
6. Hooijmans, C. M., Ras, C., and Luyben, K. Ch. A. M.: Determination of oxygen profiles in biocatalyst particles by means of a combined polarographic oxygen microsensor. Enzyme Microb. Technol., 12, 178-183 (1990).

7. De Beer, D., Stoodley, P., Roe, F., and Lewandowski, Z.: Effects of biofilm structures on oxygen distribution and mass transport. Biotechnol. Bioeng., 43, 1131-1138 (1994).

8. Wijffels, R. H., Eekhof, M. R., de Beer, D., Van den Heuvel, J. C., and Tramper, J.: Pseudo-steady state oxygen-concentration profiles in an agar slab containing growing Nitrobacter agilis. J. Ferment. Bioeng., 79, 167-170 (1995).

9. Cronenberg, C. C. H. and Van den Heuvel, J. C.: Determination of glucose diffusion coefficients in biofilms with micro-electrodes. Biosens. Bioelectron., 6, 255-262 (1991).

10. Zwietering, M. H., de Koos, J. T., Hasenack, B. G., de Wit, J. C, and Van't Riet, K.: Modelling of bacterial growth as a function of the temperature. Appl. Environ. Microb., 57, 1094-1101 (1991).

11. Schramm, M., Gromet, Z., and Hestrin, S.: Synthesis of cellulose by Acetobacter xylinum. III. Substrates and inhibitors. Biochem. J., 67, 669-679 (1957).

12. Revsbech, N.P. and Ward, D. M.: Oxygen microelectrode that is insensitive to medium chemical composition: use in an acid microbial mat dominated by Cyandium caldarium. Appl. Environ. Microbiol., 45, 755-764 (1983).

13. Müller, W., Winnefeld, A., Kohls, O., Zimelka, w., and Baumgärtl, H.: Real and pseudo oxygen gradients in Ca-alginate beads monitored during polarographic $\mathrm{Po}_{2}$-measurements using Pt-needle microelectrodes. Biotechnol. Bioeng., 44, 617-625 (1994).

14. Crank, J.: The mathematics of diffusion (2nd ed). Clarendon Press, Oxford (1975).

15. Hellendoorn, L., Mulder, H., Van den Heuvel, J. C., and Ottengraf, S.P.P.: Intrinsic kinetic parameters of the pellet forming fungus Aspergillus awamori. Biotechnol. Bioeng., 58, 478-485 (1998).

16. Masaoka, S., Ohe, T., and Sakota, N.: Production of cellulose from glucose by Acetobacter xylinum. J. Ferment. Bioeng., 75,
18-22 (1993).

17. Embuscado, M. E., Marks, J. S., and BeMiller, J. N.: Bacterial cellulose. I. Factors affecting the production of cellulose by Acetobacter xylinum. Food Hydrocoll., 8, 407-418 (1994).

18. Toda, K., Asakura, T., Fukaya, M., Entani, E., and Kawamura, Y.: Cellulose production by acid-resistant Acetobacter xylinum. J. Ferment. Bioeng., 84, 228-231 (1997).

19. Hestrin, S. and Schramm, M.: Synthesis of cellulose by Acetobacter xylinum. II. Preparation of freeze-dried cells capable of polymerizing glucose to cellulose. Biochem. J., 58, 345352 (1954).

20. Asai, T.: Acetic acid bacteria: classification and biochemical activities. University of Tokyo Press, Tokyo (1968).

21. Yang, Y. K., Park, S. H., Hwang, J. W., Pyun, Y. R., and Kim, Y.S.: Cellulose production by Acetobacter xylinum BCR5 under agitated condition. J. Ferment. Bioeng., 85, 312317 (1998).

22. Borzani, W. and de Souza, S. J.: Mechanism of the film thickness increasing during the bacterial production of cellulose on non-agitated liquid media. Biot. Lett., 17, 1271-1272 (1995).

23. Perry, R.H. and Green, P.W. (ed.): Perry's chemical engineers handbook, 6th ed., p. 3-259. McGraw-Hill Book Co., Singapore (1988).

24. Wise, D. L. and Houghton, G.: The diffusion coefficients of ten slightly soluble gases in water at $10-60^{\circ} \mathrm{C}$. Chem. Eng. Sci., 21, 999-1010 (1966).

25. Ottengraf, S. P. P.: Exhaust gas purification. In Rehm, H. J. and Reed, G. (ed.), Biotechnology, vol. 8. VCH, Weinheim, FDR (1986)

26. Dutch nutrient database $1989 / 90$. The Hague, Foundation NEVO Zeist (1989).

27. Hulst, A. C., Hens, H. J.H., Buitelaar, R. M., and Tramper, J.: Determination of the effective diffusion coefficient of oxygen in gel materials in relation to gel concentration. Biotechnol. Tech., 3, 199-204 (1989).

28. Zhou, Q. and Bishop, P. L.: Determination of oxygen profiles and diffusivity in encapsulated biomass $\kappa$-carrageenan gel beads. Wat. Sci. Tech., 36, 271-277 (1997). 